\title{
Dry Matter Accumulation and Phosphorus Utilization Efficiency in Sugar Beet (Beta vulgaris) under Varied Irrigation and Phosphorus Supply
}

\author{
Ning Wang ${ }^{1}$, Fengzhen $\mathrm{Fu}^{2}$, Jinfeng $\mathrm{Ji}^{3}$, Peng Wang ${ }^{3 *}$, Shuping $\mathrm{He}^{3}$, Hongying $\mathrm{Shao}^{3}$, Zhen $\mathrm{Ni}^{3}$ and Xingmei $\mathrm{Zhang}^{3}$ \\ ${ }^{1}$ Postdoctoral Research Station of Crop Science, Heilongjiang Bayi Agricultural University, Daqing Heilongjiang 163319, P. \\ R. China \\ ${ }^{2}$ College of Horticulture and Landscape, Heilongjiang Bayi Agricultural University, Daqing Heilongjiang 163319, P. R. \\ China \\ ${ }^{3}$ College of Agronomy, Heilongjiang Bayi Agricultural University, Daqing Heilongjiang 163319, P. R. China \\ *For correspondence: wangp.ycs@163.com \\ Received 13 August 2020; Accepted 16 November 2020; Published 10 January 2021
}

\begin{abstract}
The present study investigated the effects of irrigation and phosphorus fertilizer on dry matter accumulation and phosphorus use efficiency in sugar beet for two growing seasons during 2016 and 2017, using H003 cultivar. The experiment was comprised of four treatments including NP0K-rainfed (C1), NPK-rainfed (C2), NP0K-irrigation (C3), and NPK-irrigation (C4) using $105 \mathrm{~kg} \mathrm{P} \mathrm{ha}^{-1}$ compared with $0 \mathrm{~kg} \mathrm{P} \mathrm{ha}^{-1}$. The results showed that during the whole growth period of crop, chlorophyll contents was in the order of $\mathrm{C} 4>\mathrm{C} 3>\mathrm{C} 2>\mathrm{C} 1$. The sugar contents were higher in irrigation treatments than rain-

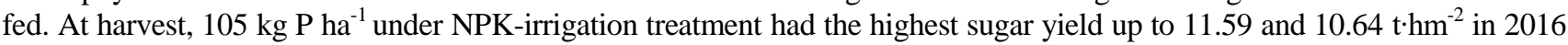
and 2017 respectively. The percent increase in yield was 20.19-27.07\%, 15.79-21.62\% and 14.57-14.93\% than C1, C2 and

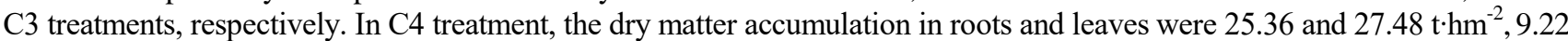
and $10.67 \mathrm{t} \cdot \mathrm{hm}^{-2}$ in 2016 and 2017 respectively, with $0.39 \%$ and 5.53, 11.61 and $25.02 \%$ higher than in C2 treatment. The phosphorus accumulation in roots of $\mathrm{C} 4$ treatment at harvesting was 9.46 and $9.97 \mathrm{t} \cdot \mathrm{hm}^{-2}$ while phosphorus accumulation in leaves of same treatment was 3.58 and $3.80 \mathrm{t} \cdot \mathrm{hm}^{-2}$ in 2016 and 2017, respectively. In irrigation treatments, the utilization efficiency of phosphate fertilizer was 16.97 and $17.33 \%$ in 2016 and 2017, respectively, with 25.52 and $29.02 \%$ higher than corresponding rainfed treatment, indicating that irrigation could significantly improve the utilization efficiency of $\mathrm{P}$ fertilizer. (C) 2021 Friends Science Publishers
\end{abstract}

Keywords: Rainfed; Sugar beet; Chlorophyll; Sugar yield; Phosphorus accumulation

\section{Introduction}

Sugar beet (Beta vulgaris L.), as an excellent sugar crop, plays an important role in agricultural production (Zhou et al. 2011). Sugar beet requires various mineral nutrients during its whole growth period, including $\mathrm{C}, \mathrm{H}, \mathrm{O}, \mathrm{N}, \mathrm{P}, \mathrm{K}$, S, Ca, Fe, B, Zn, Mn and CI, etc. (Zhou et al. 2015). Among these, $\mathrm{N}, \mathrm{P}$ and $\mathrm{K}$ are required in high amount because limited in soil therefore must be supplied in the production of sugar beets (Christmann et al. 1990). The sugar beet is a fertilizer loving crop and very sensitive to its deficiency (Fan et al. 2014, 2015). Multi-spot field tests in Northeast China showed that $\mathrm{N}$ and $\mathrm{P}$ were still the most important limiting factors to gain higher yield in beets, and $\mathrm{N}, \mathrm{P}$ and $\mathrm{K}$ fertilizers had an impact on the quality of sugar beets (Zhou et al. 2011). In most agricultural soils, total $\mathrm{P}$ content is adequate and available $\mathrm{P}$ for plants only accounts for a small proportion (Rodríguez et al. 1999; Liu et al. 2015; Soratto et al. 2015; Bai et al. 2016). The $\mathrm{P}$ in soil solution is in a dynamic equilibrium, the fixed and adsorbed $\mathrm{P}$ can be transformed into available $\mathrm{P}$ under certain conditions (Shao et al. 1991; Lin 2013; Soratto et al. 2015; Estrada-Bonilla et al. 2017; Jacobs et al. 2018). Under same field conditions, the sugar content of sugar beet decreases with the increase of $\mathrm{N}$ application, but increases with the increase of $\mathrm{P}$ application. Lack of $\mathrm{N}$ and $\mathrm{P}$ leads to an output reduction of 19 and $12 \%$ respectively, both reaching a significant level above 5\% (Rao et al. 2012; Sousa et al. 2015; Dong et al. 2016; Wu et al. 2016). Water is also very important for beet growth and development. In the rapid growth period of leafage, each plant can transpire one liter of water into the atmosphere every day, hence, a favorable water condition is conducive to the growth of beets. Northwest and North China are two main sugar beet producing regions in China,

To cite this paper: Wang N, F Fu, J Ji, P Wang, S He, H Shao, Z Ni, X Zhang (2021). Dry matter accumulation and phosphorus utilization efficiency in sugar beet (Beta vulgaris L.) under varied irrigation and phosphorus supply. Intl J Agric Biol 25:513-520 
where drought condition prevails due to the temperate continental climate. Compared to the two regions, Northeast China is better in water conditions for it has the temperate monsoon humid climate (Chen et al. 2011; Xu et al. 2012). Water and fertilizer technologies not only reduce water and fertilizers inputs but also help to achieve high-quality products and high yield (Zhou et al. 2015; Liu et al. 2016). But few studies report combined effects of irrigation water and $\mathrm{P}$ fertilizer in Northeast China. This study measured the chlorophyll content, sugar content, biomass, plant $\mathrm{P}$ content of sugar beets at different growth stages under different $\mathrm{P}$ and water conditions. The $\mathrm{P}$ utilization efficiency was also analyzed, aiming to determine the effects of irrigation and $\mathrm{P}$ fertilizer on sugar beet. The results will provide deeper understanding the effects of $\mathrm{P}$ and water on beets and will be used as reference study.

\section{Materials and Methods}

\section{Experimental location}

This experiment was carried out at an experimental station of Heilongjiang Bayi Agricultural University in 2016 and 2017. The station is located in Daqing $\left(46^{\circ} 37^{\prime} \mathrm{N}\right.$ and $\left.125^{\circ} 11^{\prime} \mathrm{E}\right)$, China. Experimental field was fallow before the study. The soil type is meadow chernozem. And the basic physico-chemical features were: $\mathrm{pH}, 8.67$ and 8.42; soil organic matter, $27.2 \mathrm{~g} \cdot \mathrm{kg}^{-1}$ and $26.9 \mathrm{~g} \cdot \mathrm{kg}^{-1}$; available $\mathrm{N}, 129.98 \mathrm{mg} \cdot \mathrm{kg}^{-1}$ and 136.02 $\mathrm{mg} \cdot \mathrm{kg}^{-1}$; available $\mathrm{P}, 31.41 \mathrm{mg} \cdot \mathrm{kg}^{-1}$ and $30.55 \mathrm{mg} \cdot \mathrm{kg}^{-1}$; available $\mathrm{K}, 171.54 \mathrm{mg} \cdot \mathrm{kg}^{-1}$ and $179.00 \mathrm{mg} \cdot \mathrm{kg}^{-1}$ in 2016 and 2017, respectively. The conventional fertilization amounts were: $\mathrm{N}, 120.00 \mathrm{~kg} \cdot \mathrm{hm}^{-2} ; \mathrm{P}_{2} \mathrm{O}_{5}, 105.00 \mathrm{~kg} \cdot \mathrm{hm}^{-2}$; and $\mathrm{K}_{2} \mathrm{O}, 120.00 \mathrm{~kg} \cdot \mathrm{hm}^{-2}$. The precipitation and average 10-day air temperature in sugar beet growth period in 2016 and 2017 are given in Fig. 1.

\section{Materials}

The beet variety Dutch H003 (Syngenta, Germany) was used as materials in the study. Daqing urea (N content, 46\%; PetroChina Daqing Petrochemical Company, China), concentrated superphosphate $\left(\mathrm{P}_{2} \mathrm{O}_{5}\right.$ content, $46 \%$; Yunnan Yuntianhua Co., Ltd., China) and Red Bull Kalium $\left(\mathrm{K}_{2} \mathrm{O}\right.$ content, 50\%; German $\mathrm{K}+\mathrm{S}$ Group) were used as $\mathrm{N}, \mathrm{P}$, and $\mathrm{K}$ fertilizers, respectively.

\section{Experimental design}

Four treatments were set in the experiment: NP0K-rain (C1); NPK-rain (C2); NP0K-irrigation (C3); NPKirrigation $(\mathrm{C} 4)$. The fertilizers applied in $\mathrm{C} 1$ and $\mathrm{C} 3$ were: N, $120.00 \mathrm{~kg} \cdot \mathrm{hm}^{-2} ; \mathrm{P}_{2} \mathrm{O}_{5}, 0 \mathrm{~kg} \cdot \mathrm{hm}^{-2} ; \mathrm{K}_{2} \mathrm{O}, 120.00$ $\mathrm{kg} \cdot \mathrm{hm}^{-2}$, while in $\mathrm{C} 2$ and $\mathrm{C} 4$ were: $\mathrm{N}, 120.00 \mathrm{~kg} \cdot \mathrm{hm}^{-2}$, $\mathrm{P}_{2} \mathrm{O}_{5}: 105.00 \mathrm{~kg} \cdot \mathrm{hm}^{-2}, \mathrm{~K}_{2} \mathrm{O}: 120.00 \mathrm{~kg} \cdot \mathrm{hm}^{-2}$. Dutch H003 seeds were sown on May 1st and May 5th, and harvested on October $11^{\text {th }}$ and October $14^{\text {th }}$ in 2016 and 2017 respectively. The planting density was 76950 plants $\cdot \mathrm{hm}^{-2}$.

Ridge seeding method was adopted, and fertilizer was applied at $5.00 \mathrm{~cm}$ away from the ridge at $15.00 \mathrm{~cm}$ soil depth for all the four treatments. C3 and C4 were irrigated before sowing and at the foliage quick growing stage (sixleaf stage). The irrigation amount was $500 \mathrm{~mL} /$ plant for each of the two irrigations. Randomized block design with three repetitions was adopted in the experiment. Each plot was $2.6 \mathrm{~m} \times 8 \mathrm{~m}$ in size. There were 4 rows of plants in one plot, with row spacing of $0.65 \mathrm{~m}$. Plants within a row were $0.20 \mathrm{~m}$ apart from each other, and the density was 76,950 plants $/ \mathrm{hm}^{2}$.

\section{Sampling and measurement methods}

Plant sampling: One or two beet plant (s) were sampled from each plot at every growing stage of sugar beet. The samples were dehydrated at $105^{\circ} \mathrm{C}$ for $30 \mathrm{~min}$, and then dried at $75-80^{\circ} \mathrm{C}$ to constant weight. After weighing, the leaves and roots were separately smashed, bagged, numbered and kept in dry environment. Each sample was repeated 3 times.

The soil plant analysis development (SPAD) (TYS-A, Zhejiang Top Instrument Co., Ltd., China) value of every treated leaf was measured at the seedling growth, rossette formation, tuber growth, sucrose accumulation, and harvest stages from 3 beet plants.

Sugar content determination: Ten root tubers per plot were measured by hand-held sugar meter (PAL-1, ATAGO, Japan). After the sugar content was measured, large, medium and small roots tubers were taken in proportion for juicing, and one piece was cut at an angle of $45^{\circ}$ from the root head to the root body.

Dry matter accumulation: A well-developed plant was chosen at each growing stage for dry matter measurement. After cleaned by water, the fresh leaves and roots of sampled plant were separated and weighed. These were then dehydrated under $105^{\circ} \mathrm{C}$ for $30 \mathrm{~min}$. After that, the leaves were cut up and the root was sliced. The leaf and root pieces were separately dried to a constant weight at $75^{\circ} \mathrm{C}$, cooled down at room temperature, and weighed again.

Plant P content determination: The dried samples were grinded and then screened with a $0.25-\mathrm{mm}$ sieve. A $0.4 \mathrm{~g}$ samples was then taken and heated with $\mathrm{H}_{2} \mathrm{SO}_{4}-\mathrm{HClO}_{4}$ to determine the $\mathrm{P}$ content by Mo-Sb colorimetry.

$\mathrm{P}$ fertilizer utilization efficiency: $\mathrm{P}$ fertilizer utilization efficiency is the percentage of the difference in $P$ accumulation between the $\mathrm{P}$ fertilizer applied treatment and the no $\mathrm{P}$ applied treatment.

\section{Statistical analysis}

Data were analyzed using S.P.S.S. 21.0 and Excel 2016, and $t$-test was used to determine the significance of difference. 


\section{Results}

Effects of limited irrigation and $P$ application on the chlorophyll values

The chlorophyll values of sugar beets in the four treatments all gradually increased with plants growing, and peaked at harvest time (Fig. 2 and 3). During the whole growth period of sugar beet crop, the chlorophyll values were in the following order: $\mathrm{C} 4>\mathrm{C} 3>\mathrm{C} 2>\mathrm{C} 1$. At seedling stage, the highest SPAD-chlorophyll value in $\mathrm{C} 4$ was 27.37 and 25.27 in 2016 and 2017 respectively, which was 14.98 and $6.33 \%$ higher than C2; the SPAD-chlorophyll in C3 was 23.83 and 24.07 in 2016 and 2017 respectively, which was 33.15 and $11.80 \%$ higher than in $\mathrm{C} 1$. There was no significant difference $(P>0.05)$ in SPAD-chlorophyll among the four treatments at the foliage quick growing stage, the tuber growth stage and the sugar accumulation stage, but the chlorophyll values in the irrigation treatments were higher than in the rain-fed treatments under the same fertilizer conditions. At the harvest time, the leaf chlorophyll values of the four treatments were ranked as: $\mathrm{C} 4>\mathrm{C} 3>\mathrm{C} 2>\mathrm{C} 1$ ), and $\mathrm{C} 4>\mathrm{C} 3>\mathrm{C} 2>\mathrm{C} 1$ in 2016 and 2017, respectively. The chlorophyll value in $\mathrm{C} 4$ treatment was 112.63 and $113.29 \%$, and 113.69 and $113.79 \%$ than in $\mathrm{C} 2$ and $\mathrm{C} 1$ treatments for 2016 and 2017, respectively. The results showed that the application of $\mathrm{P}$ fertilizer under the same $\mathrm{N}$ and potassium condition improved the chlorophyll content of beet plants, and irrigation was more conducive to chlorophyll content than the rain-fed treatment. At the same growth stage of sugar beets, the chlorophyll content was higher in 2016 than in 2017, and the difference was significant $(P<0.05)$. This might be because the precipitation was more in 2016 than in 2017.

\section{Effects of limited irrigation and $P$ application on sugar content and sugar yield}

With the progress of growth period, the sugar content of sugar beets increased gradually, showing a trend of rapid growth followed by slow growth (Table 1). In the whole growth period, the sugar content of irrigation treatments was greater than rain-fed treatments in the two years. The results showed that irrigation could promote the increase of sugar content, and the sugar content of $\mathrm{C} 4$ treatment was the highest, while $\mathrm{C} 1$ treatment had the lowest in the whole growth period. In general, the sugar content of each treatment under supplementary irrigation was higher than under rain-fed condition, and the $\mathrm{P}$ application treatment was higher than without $\mathrm{P}$ application, indicating that both irrigation and $\mathrm{P}$ application significantly affected the sugar content of sugar beets.

Under water and fertilizer treatments, the sugar yields were higher than under rain-fed treatments, and the sugar yield of $\mathrm{P}$ treatment was higher than no $\mathrm{P}$ treatment in 2016 and 2017 respectively (Fig. 4 and 5). C4 treatment had the highest sugar yield up to $11.59 \pm 0.59$ and $10.64 \pm 0.89$ $\mathrm{t} \cdot \mathrm{hm}^{-2}$ in 2016 and 2017 respectively, while $\mathrm{C} 1$ treatment had the lowest sugar yield i.e., $9.25 \pm 0.35$ and $7.76 \pm 0.53$ $\mathrm{t} \cdot \mathrm{hm}^{-2}$, in 2016 and 2017 respectively.

\section{Effects of limited irrigation and $P$ application on dry matter accumulation in beets}

Dynamic changes of dry matter accumulation in roots: The dry matter accumulation of beet roots showed a rapid increase along the growth period in both 2016 and 2017 (Fig. 6 and 7). From the seedling stage to the tuber growth stage, the dry matter accumulation of roots in each treatment increased slowly. The accumulated dry matter in irrigation treatments was greater than in rain-fed treatment, but there was no significant difference between $\mathrm{C} 4$ and $\mathrm{C} 3$ treatments, and between $\mathrm{C} 2$ and $\mathrm{C} 1$ treatments $(P>0.05)$. From the sugar accumulation stage to the harvest time, the dry matter accumulation in roots increased rapidly and reached the highest value at harvest. C4 treatment had the highest dry matter accumulation, with the values of $25.36 \pm$ 1.93 and $27.48 \pm 1.71 \mathrm{t} \cdot \mathrm{hm}^{-2}$ in 2016 and 2017 , respectively, while $\mathrm{C} 1$ treatment had the lowest dry matter accumulation up to $20.91 \pm 2.25$ and $15.79 \pm 3.45 \mathrm{t} \cdot \mathrm{hm}^{-2}$ in 2016 and 2017, respectively. The results showed that the irrigation treatments could significantly increase the dry matter accumulation in roots.

Dynamic changes of dry matter accumulation in leaves: The dry matter accumulation in the leaves of sugar beets showed the same pattern as in the roots (Fig. 8 and 9). At harvest, the dry matter accumulation in leaves in C4 treatment was the highest with values up to $9.22 \pm 0.53$ $\mathrm{t} \cdot \mathrm{hm}^{-2}$ in 2016 and $10.67 \pm 0.56 \mathrm{t} \cdot \mathrm{hm}^{-2}$ in 2017 , while the dry matter accumulation in $\mathrm{C} 1$ treatment was the lowest, with the value of $7.58 \pm 0.98$ and $6.02 \pm 1.08 \mathrm{t} \cdot \mathrm{hm}^{-2}$ in 2016 and 2017, respectively.

\section{Effects of limited irrigation and $P$ application on $P$ accumulation in sugar beets}

Dynamic changes of $\mathbf{P}$ accumulation in roots: The accumulation of $\mathrm{P}$ in sugar beet roots showed an exponential increase trend with sugar beet growth (Fig. 10 and 11). The coefficient $\left(R^{2}\right)$ of the exponential regression fitting equation of every treatment was greater than 0.97 . The accumulation of $\mathrm{P}$ in the roots of sugar beets with applied $\mathrm{P}$ was greater than without $\mathrm{P}$ application in every growth period during both years. The $\mathrm{P}$ accumulation in roots ranked in the following order: $\mathrm{C} 4>\mathrm{C} 3, \mathrm{C} 2>\mathrm{C} 1$. The $\mathrm{P}$ accumulation in roots under irrigation treatments were greater than under the rain-fed condition, and ranked as follows: $\mathrm{C} 4>\mathrm{C} 2, \mathrm{C} 3>\mathrm{C} 1$. At the harvest time, the $\mathrm{P}$ accumulations in the roots were significantly different among the four treatments $(P<0.05)$ and ranked as follows: C4 $\left(9.46 \pm 0.75 \mathrm{~kg} \cdot \mathrm{hm}^{-2}\right)>\mathrm{C} 2(7.46 \pm$ $\left.0.48 \mathrm{~kg} \cdot \mathrm{hm}^{-2}\right)>\mathrm{C} 3\left(3.54 \pm 0.34 \mathrm{~kg} \cdot \mathrm{hm}^{-2}\right)>\mathrm{C} 1(3.08 \pm 0.36$ $\left.\mathrm{kg} \cdot \mathrm{hm}^{-2}\right)$ in 2016 and C4 $\left(9.97 \pm 0.87 \mathrm{~kg} \cdot \mathrm{hm}^{-2}\right)>\mathrm{C} 2(8.22 \pm$ 
Wang et al. / Intl J Agric Biol, Vol 25, No 2, 2021

Table 1: Effects of limited irrigation and phosphorus application on sugar content of sugar beets at different growth stages

\begin{tabular}{lllll}
\hline Year & Treatment & Tuber growth stage $(\%)^{1}$ & Sugar accumulation stage $(\%)$ & Harvest time $(\%)$ \\
\hline 2016 & $\mathrm{C} 1$ & $10.30 \mathrm{c} \pm 0.17$ & $12.67 \mathrm{~b} \pm 0.46$ & $13.93 \mathrm{c} \pm 0.29$ \\
& $\mathrm{C} 2$ & $12.80 \mathrm{~b} \pm 0.26$ & $12.97 \mathrm{~b} \pm 0.21$ & $14.77 \mathrm{~b} \pm 0.21$ \\
& $\mathrm{C} 3$ & $13.47 \mathrm{a} \pm 0.42$ & $14.53 \mathrm{a} \pm 0.42$ & $16.47 \mathrm{a} \pm 0.21$ \\
& $\mathrm{C} 4$ & $13.77 \mathrm{a} \pm 0.06$ & $14.57 \mathrm{a} \pm 0.12$ & $16.87 \mathrm{a} \pm 0.15$ \\
\hline 2017 & $\mathrm{C} 1$ & $8.23 \mathrm{c} \pm 0.42$ & $15.87 \mathrm{~d} \pm 0.11$ & $16.43 \mathrm{c} \pm 0.23$ \\
& $\mathrm{C} 2$ & $10.80 \mathrm{a} \pm 0.21$ & $16.20 \mathrm{c} \pm 0.15$ & $17.23 \mathrm{~b} \pm 0.20$ \\
& $\mathrm{C} 3$ & $10.20 \mathrm{~b} \pm 0.20$ & $16.53 \mathrm{~b} \pm 0.13$ & $17.57 \mathrm{~b} \pm 0.31$ \\
& $\mathrm{C} 4$ & $10.90 \mathrm{a} \pm 0.30$ & $16.94 \mathrm{a} \pm 0.24$ & $18.60 \mathrm{a} \pm 0.46$ \\
\hline \multicolumn{7}{l}{ Data are presented as mean \pm SD } & &
\end{tabular}

${ }^{2}$ Different lowercase letters within the same column indicate significant differences among different treatments $(P<0.05)$

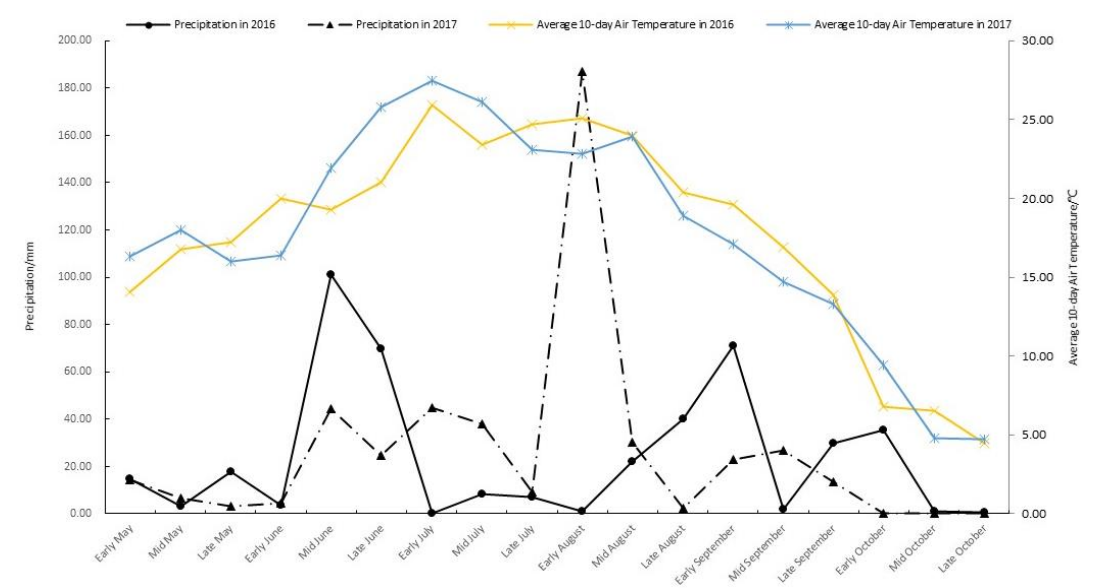

Fig. 1: Precipitation and average 10-day temperature in sugar beet growth period in 2016 and 2017

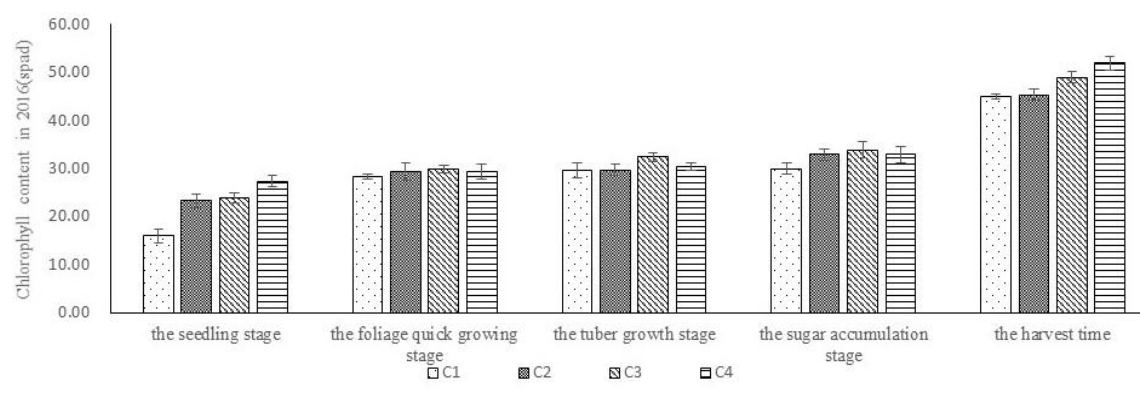

Fig. 2: Effects of limited irrigation and phosphorus application on chlorophyll content in sugar beets in 2016

$\left.0.52 \mathrm{~kg} \cdot \mathrm{hm}^{-2}\right)>\mathrm{C} 3\left(3.82 \pm 0.50 \mathrm{~kg} \cdot \mathrm{hm}^{-2}\right)>\mathrm{C} 1(3.13 \pm 0.41$ $\mathrm{kg} \cdot \mathrm{hm}^{-2}$ ) in 2017. The results showed that irrigation conducted at the foliage quick growing stage and $\mathrm{P}$ fertilizer increased the $\mathrm{P}$ content in roots by $17.55-18.06 \%$ and 61.69 $61.92 \%$, respectively.

Dynamic changes of $\mathbf{P}$ accumulation in leaves: The $P$ accumulation in beet leaves showed a power increasing trend as sugar beets grew in 2016 and 2017 (Fig. 12 and 13). The coefficients $\left(\mathrm{R}^{2}\right)$ of the power function fitting equation of four treatments were all greater than 0.95 . The $P$ accumulation in leaves of sugar beets applied with $\mathrm{P}$ was greater than without $\mathrm{P}$ application at every growth stage in the two years, and ranked as follows : C4 treatment $>\mathrm{C} 3$ treatment, $\mathrm{C} 2$ treatment $>\mathrm{C} 1$ treatment. The $\mathrm{P}$ accumulation in leaves of sugar beets under the irrigation treatments was also greater than under the rain-fed treatments, that is the $\mathrm{P}$ accumulation in leaves was ranked in the following order: $\mathrm{C} 4$ treatment $>\mathrm{C} 2$ treatment, $\mathrm{C} 3$ treatment $>\mathrm{C} 1$ treatment. At harvest, the $\mathrm{P}$ accumulation in leaves was significantly different $(P<0.05)$ among the four treatments and ranked in the following order: $\mathrm{C} 4\left(3.58 \pm 0.23 \mathrm{~kg} \cdot \mathrm{hm}^{-2}\right)>\mathrm{C} 2(2.83 \pm$ $\left.0.19 \mathrm{~kg} \cdot \mathrm{hm}^{-2}\right)>\mathrm{C} 3\left(1.72 \pm 0.22 \mathrm{~kg} \cdot \mathrm{hm}^{-2}\right)>\mathrm{C} 1(1.41 \pm 0.17$ $\left.\mathrm{kg} \cdot \mathrm{hm}^{-2}\right)$ in 2016 and C4 $\left(3.80 \pm 0.24 \mathrm{~kg} \cdot \mathrm{hm}^{-2}\right)>\mathrm{C} 2(2.26 \pm$ $\left.0.25 \mathrm{~kg} \cdot \mathrm{hm}^{-2}\right)>\mathrm{C} 3\left(2.01 \pm 0.21 \mathrm{~kg} \cdot \mathrm{hm}^{-2}\right)>\mathrm{C} 1(1.71 \pm 0.22$ $\mathrm{kg} \cdot \mathrm{hm}^{-2}$ ) in 2017 . The results showed that both irrigation at the foliage quick growing stage and $\mathrm{P}$ application affected the $\mathrm{P}$ accumulation in beet leaves, with the $\mathrm{P}$ content in leaves was increased by $14.93-40.53 \%$ under irrigation treatments and by $24.34-47.11 \%$ under treatments with $\mathrm{P}$ supplied. 


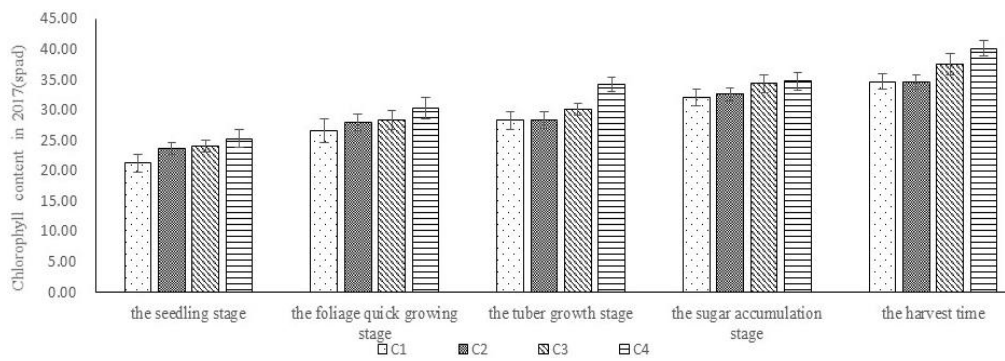

Fig. 3: Effects of limited irrigation and phosphorus application on chlorophyll content in sugar beets in 2017

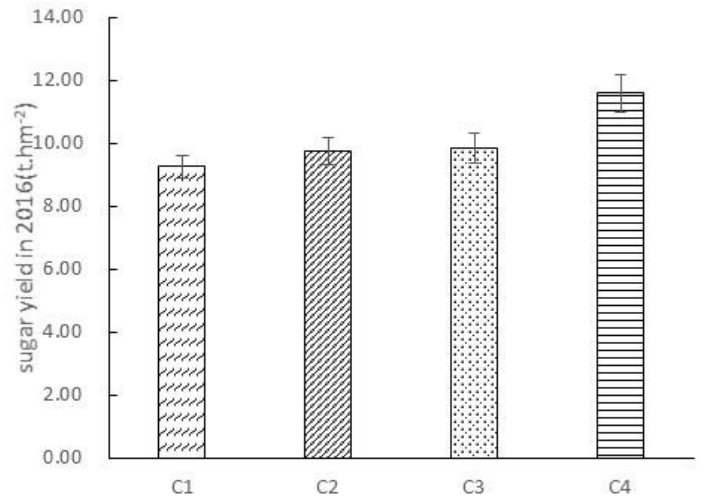

Fig. 4: Effects of limited irrigation and phosphorus application on sugar yield of sugar beets in 2016

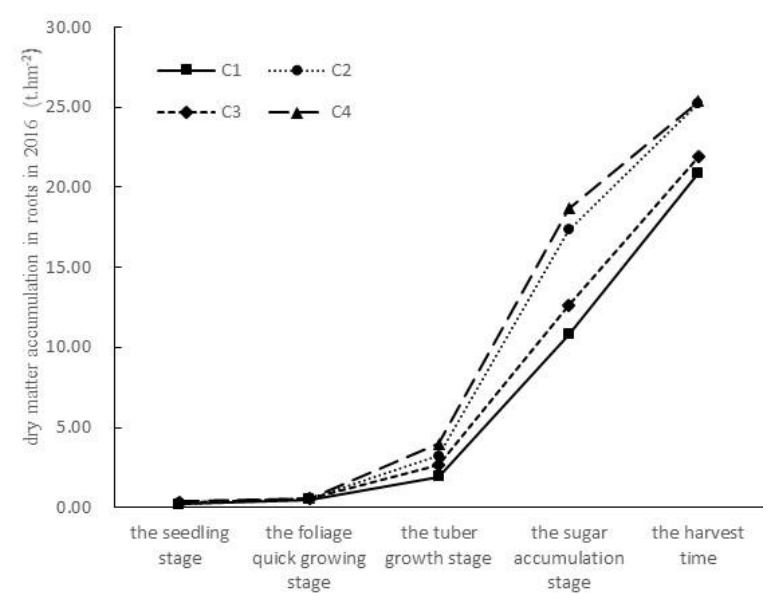

Fig. 6: Effects of limited irrigation and phosphorus application on dry matter accumulation in beet roots in 2016

\section{Effects of limited irrigation and $P$ application on $P$ utilization efficiency of sugar beets}

The phosphate utilization efficiency in $\mathrm{C} 4$ treatment was $16.97 \pm 0.95 \%$ and $17.33 \pm 1.51 \%$ in 2016 and 2017 respectively, which was 25.52 and $29.02 \%$ higher than in $\mathrm{C} 2$ treatment. The $\mathrm{P}$ utilization efficiency difference between $\mathrm{C} 4$ and $\mathrm{C} 2$ was significant $(P<0.05)$, indicating that irrigation at the foliage quick growing stage of sugar beets significantly improved $\mathrm{P}$ fertilizer utilization

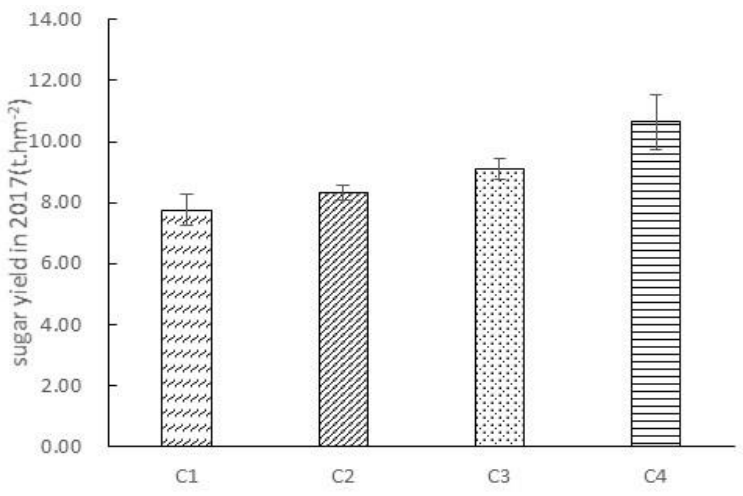

Fig. 5: Effects of limited irrigation and phosphorus application on sugar yield of sugar beets in 2017

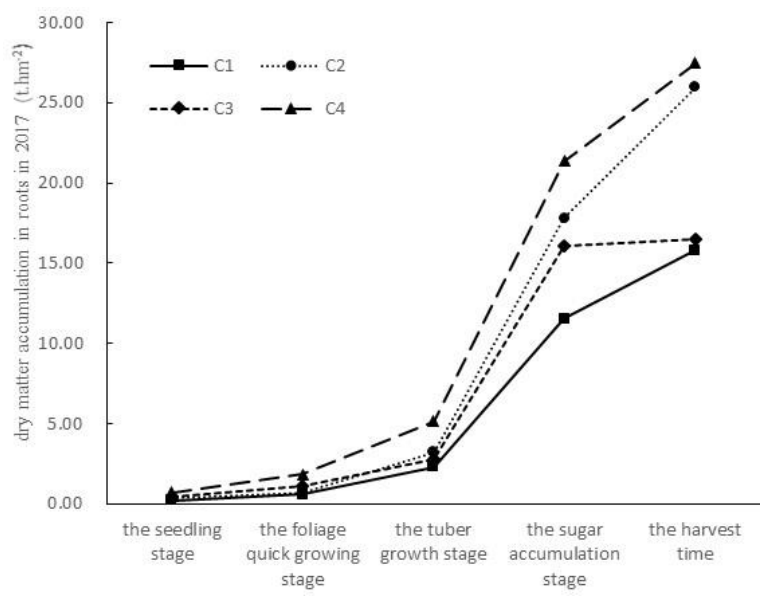

Fig. 7: Effects of limited irrigation and phosphorus application on dry matter accumulation in beet roots in 2017

efficiency.

\section{Discussion}

Phosphorus $(\mathrm{P})$ is one of the most important elements that affect plant photosynthesis and the distribution of photonic compounds between roots and overground parts (Yu et al. 2014). Chlorophyll is closely associated with the growth and development of sugar beets, and the difference can to some extent reflect the P content of the plant. The size of the 


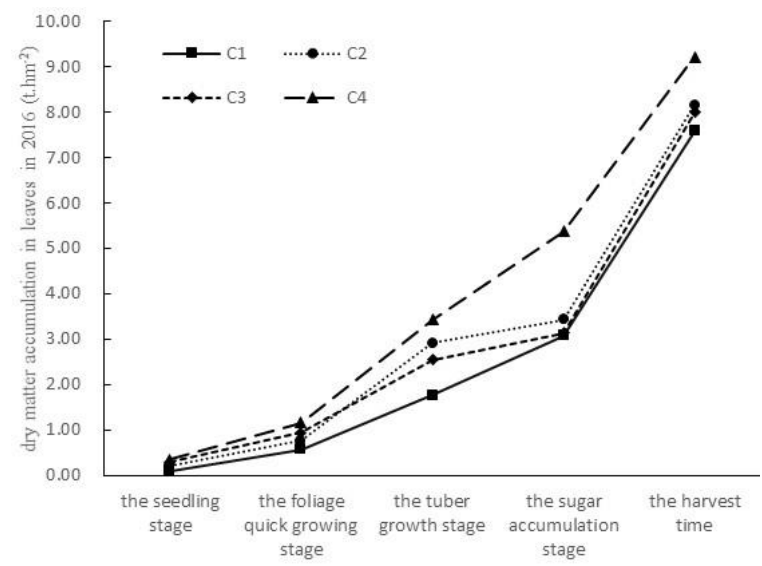

Fig. 8: Effects of limited irrigation and phosphorus application on dry matter accumulation in beet leaves in 2016

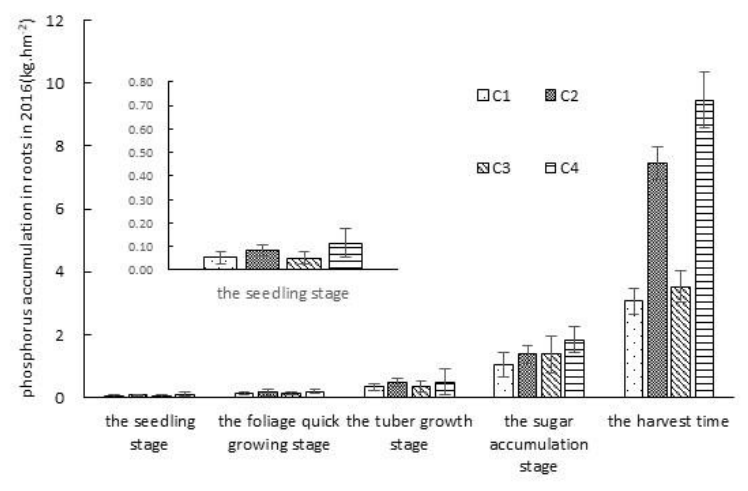

Fig. 10: Effects of limited irrigation and phosphorus application on phosphorus accumulation in beet roots in 2016

photosynthetic system of sugar beet is significantly positively affected by the $\mathrm{P}$ level in plants. The chlorophyll content plays an important role in the yield formation, and the application of $\mathrm{P}$ fertilizer can improve the photosynthetic rate of plants through increasing leaf chlorophyll content (Qu et al. 2001; Li et al. 2019). Yang et al. (2018) concluded that adequate fertilizer combined with water supplement could significantly increase chlorophyll content in rice. The present study and $\mathrm{Qu}$ et al. (2001) both concluded that leaf chlorophyll content increased gradually along with the growth of sugar beets. In addition, leaf chlorophyll content improved with the increase of applied P and water, as evidence from the study, Gao et al. (2017) on the apple-maize intercropping system and Yang et al. (2018) on rice.

The final sugar yield of sugar beets is determined by the number of plants per unit area, the yield of root tubers and sugar content of beets (Su et al. 2016). Wang et al. (2011) observed that under the same fertility conditions, the sugar content of sugar beets increased with the increase of $P$ fertilizer; Du (2012) also showed that during the growth of sugar beets, $\mathrm{P}$ fertilizer was conducive to the increase of

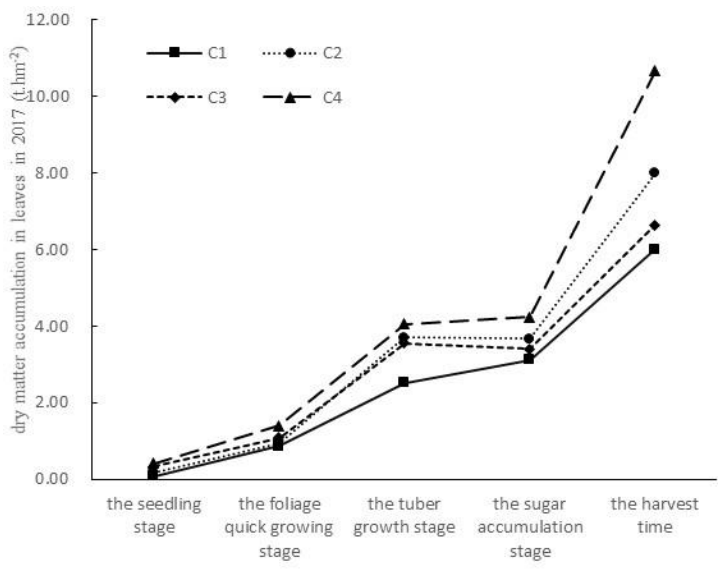

Fig. 9: Effects of limited irrigation and phosphorus application on dry matter accumulation in beet leaves in 2017

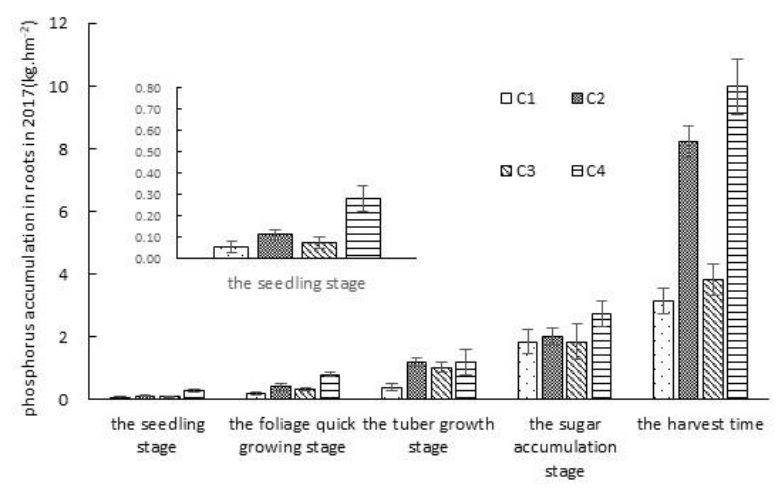

Fig. 11: Effects of limited irrigation and phosphorus application on phosphorus accumulation in beet roots in 2017

sugar content and could promote the growth and development of root tubers. If the supply of $\mathrm{P}$ is relatively insufficient, it is bound to affect the expansion of root tubers of beets, thus affecting the formation of root yield. Zhang and $\mathrm{Li}$ (1997) showed that application of P fertilizer alone could increase the yield of beets by $29-63 \%$, and combined with $\mathrm{N}, \mathrm{P}$ fertilizer could increase the sugar content of beets by $0.2 \%$ on average, indicating that application of $\mathrm{P}$ fertilizer could promote the accumulation of sugar in roots of sugar beets to some extent. In this study, C4 treatment's sugar content and tuber yield were increased by $2.37-5.54 \%$ and $9.55-14.93 \%$ respectively based on $\mathrm{C} 3$ treatment; $\mathrm{C} 2$ treatment were increased by $4.64-5.68 \%$ and $2.38-5.23 \%$ respectively based on $\mathrm{C} 1$ treatment, showing that $\mathrm{P}$ fertilizer has great impact on sugar beets' sugar content and tuber production. The reason may be that under the condition of same $\mathrm{N}$ application, increasing $\mathrm{P}$ dosage can improve the activity of total sugar $\mathrm{P}$ synthetase in beets, which is conducive to the formation of total sugar and its delivery to tubers and to promote root system development, tuber growth and accumulation of sugar in beets. In addition, plenty of phosphate fertilizer promoted the development of 


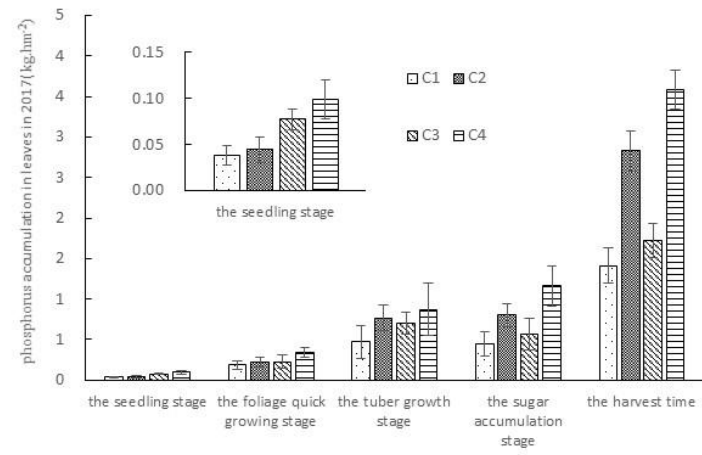

Fig. 12: Effects of limited irrigation and phosphorus application on phosphorus accumulation in beet leaves in 2016

beet roots, and helped beets to absorb nutrients from the soil to meet the demand of sugar beets for nutrient elements, creating conditions for the high yield of beets. Besides, when fertilizers were adequate, supplementation of water could also significantly increase production (Yang et al. 2018).

Application of $\mathrm{P}$ fertilizer and proper irrigation can promote the accumulation of dry matter and $\mathrm{P}$ in the roots and leaves to increase continuously throughout the growth period (Fu et al. 2011; Qin et al. 2019; Ren et al. 2019). In this study, there was a positive correlation between dry matter accumulation and $\mathrm{P}$ accumulation in all treatments; supplementary irrigation in the growth period could effectively improve the dry matter content and $\mathrm{P}$ accumulation of plants at a significant level. Among the treatments, C4 treatment's dry matter mass and $\mathrm{P}$ accumulation were the largest in each growth period.

In crop planting, Appropriate application of $\mathrm{P}$ fertilizer and irrigation can improve the utilization efficiency of $\mathrm{P}$ fertilizer for sustainable development of agriculture ( $\mathrm{Li}$ and Pan 2002; Fu et al. 2011; Zheng et al. 2014; Xu 2015; Qin et al. 2019). The results of this experiment showed that under proper irrigation, the utilization efficiency of $\mathrm{P}$ fertilizer by beets was higher than under rain-fed condition.

\section{Conclusion}

With the same $\mathrm{P}$ applied, sugar beets under proper irrigation have a better performance in chlorophyll, sugar content, dry matter accumulation, and $\mathrm{P}$ utilization efficiency than under rain-fed treatments. These results suggested that the growth indices and yield of sugar beets were optimal under conventional fertilization and irrigation management practices.

\section{Acknowledgements}

The authors acknowledge the National Beet Modern Agriculture Industry Technology System Soil Fertilizer Post, China (Grant No. CARS-210306-02) and the Doctoral

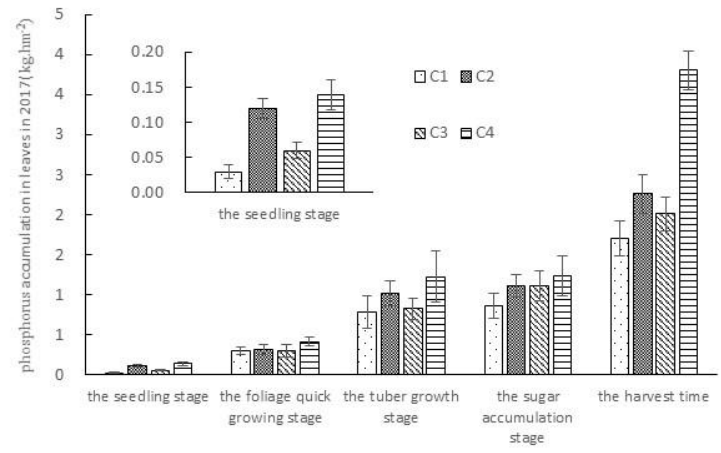

Fig. 13: Effects of limited irrigation and phosphorus application on phosphorus accumulation in beet leaves in 2017

Scientific Research Foundation (Grant No. XDB2015-02) of Heilongjiang Bayi Agricultural University, China.

\section{Author Contributions}

Ning Wang and Peng Wang planned the experiments, Fengzhen Fu, Jinfeng Ji and Shuping He interpreted the results, Ning Wang made the write up and Hongying Shao, Zhen Ni and Xingmei Zhang statistically analyzed the data and made illustrations.

\section{References}

Bai XH, HJ Liu, M Lin, JH Pan, CY Li (2016). Influence of different fertilization levels on botanical trait, yield and sugar content of sugar beet. Sugar Crops Chin 38:24-28

Chen JJ, FC Zhang, HM Zhou, YG Zhao, XG Wei (2011). Effect of irrigation at different growth stages and nitrogen fertilizer on maize growth, yield and water use efficiency. $J N W$ Agric For Univ Nat Sci Ed 1:89-95

Christmann J, G Guiraud, Y Lindemann (1990). Application of Nitrogen Fertilizer to Sugarbeet, Nitrates-agriculture-eau: International Symposium, Paris, France

Dong XJ, HZ Yang, WS Gao, YF Wang (2016). Effects of planting population on yield and quality of different type of sugar beet. Sugar Crops Chin 38:30-31

Du YC (2012). Effects of NPK application levels on photosynthetic capacity and nitrogen metabolism key enzymes in sugar beet. Northeast Agricultural University, Harbin, China

Estrada-Bonilla GA, CM Lopes, A Durrer, RLA Paulo, P Nicolle, EJBN Cardoso (2017). Effect of phosphate-solubilizing bacteria on phosphorus dynamics and the bacterial community during composting of sugarcane industry waste. Syst Appl Microbiol 40:308-313

Fan H, QY Geng, Paniguli, F Lin, FY Ma (2014). Effect of plastic mulching on growing stage and yield of drip irrigated sugarbeet. Xinj Agric Sc $51: 2157-216$

Fan SH, JL Zheng, BC Sun, L Bian, WL Kan, ZH Rong, X Chen (2015). Introduction experiment of sugar beet variety H004. Sugar Crops Chin 37:45-46

Fu LD, Y Wang, X Li, X Sui, H Ren, BJ Li (2011). Effects of different phosphorus fertilizer amount on yield and utilization efficiency North Rice 41:20-24

Gao F, RS Wang, HS Xu, DM Wang, ZR Yang (2017). Analysis of crop growth and economic benefit in an apple-maize intercropping system under water and fertilizer coupling. Agric Res Arid Areas 35:20-28 
Jacobs A, HJ Koch, B Märländer (2018). Preceding crops influence agronomic efficiency in sugar beet cultivation. Agron Sustain Dev 38; Article 5

Li F, XH Pan (2002). The Research development of morphological and physiological characteristics of plant root system under phosphorus deficiency. Chin Agric Sci Bull 18:65-69

Li J, TT Duan, C Zheng, Z Lin, YQ Liang, Y Gao, K Deng (2019). The photosynthesis and growth characteristics of two sugarcane cultivars in different phosphorus rate condition. Chin J Trop Crops 40:1108-1114

Lin F (2013). Interaction of water and nitrogen on the yield and sugar content of sugar beet under plastic mulching with drip irrigation $(P M D I)$. Shihezi University, Shihezi, Xinjiang, China

Liu HJ, YF Wang, R Huang, XJ Dong (2016). Research progress on nitrogen fertilizer application in sugar beet. Sugar Crops Chin 38:30-31

Liu N, ZS Yan, YJ Fan, BQ Song, HL Jia, J Yang (2015). Effect of different nitrogen application levels on the content of soluble protein and key enzyme activities in nitrogen metabolism of sugar beet. Chin Agric Sci Bull 31:149-154

Qin YL, YH Tian, MS Fan, XH Shi, LG Jia, Y Chen, J Yu (2019). Effect of different phosphorous fertilizer kinds on potato yield and Phosphorus use efficiency in Calcareous Soil. Chin Veg 39:70-75

Qu WZ, LQ Geng, MZ Gao (2001). Affection of phosphorus level to sugarbeet photosynthesis. Chin Beet Sugar 3:8-11

Rao BY, SQ Luo, ZJ Wu, C Qian (2012). The effect of water and fertilizer coupling on yield and quality of angelica. Chin Agric Sci Bull 28:274-278

Ren YF, ZY Lu, J Nie, Y Cui, H An, Y Gao, PY Zhao (2019). Effects of pre-seedling drip irrigation on water utilization and yield of potato. $J$ North Agric 47:66-72

Rodríguez D, FH Andrade, J Goudriaan (1999). Effects of phosphorus nutrition on tiller emergence in wheat. Plant Soil 209:283-295

Shao JW, B Cai, JH Zhang (1991). Beet Physiology. Agricultural Publishing House, Beijing, China
Soratto RP, C Pilon, AM Fernandes, LA Moreno (2015). Phosphorus uptake, use efficiency, and response of potato cultivars to phosphorus levels. Potato Res 58:121-134

Sousa RTXD, GH Korndörfer, RAB Soares, PR Fontoura (2015). Phosphate fertilizers for sugarcane used at pre-planting (phosphorus fertilizer application). J Plant Nutr 38:1444-1455

Su JX, KY Wang, C Fei, YY Li, H Fan (2016). Effects of nitrogen management on sugar beet yield, nitrogen uptake and soil nitrogen balance under drip irrigation. Chin J Soil Sci 47:1404-1408

Wang YB, FM Ma, QX Wang (2011). Effects of fertilization on yield and quality of sugar beet. Crops 4:78-81

Wu JY, YF Zhang, SY Zhang, SQ Wang (2016). Coupling effects of water and fertilizer on roots yield and quality of sugar beet of plastic film mulching cultivation. J Irrig Drain 35:87-91

Xu GW, HZ Wang, MC Chen, YJ Li (2012). Effect of coupling between water and fertilizer on wheat yield and rhizosphere in soil. Crops $1: 35-38$

$\mathrm{Xu} \mathrm{Y}$ (2015). Effects of water and fertilizer coupling on rice growth and utilization rate of nitrogen. Hunan Agric Univ, Changsha, China

Yang B, BZ Guo, RF Guo (2018). Effect of water and fertilizer coupling on photosynthetic characteristic in rice. Chin J Trop Crops 39:1311-1317

Yu X, JX Huang, YB Wang, ZW Diao, CF Li, ZJ Gai, FM Ma (2014) Effect of nitrogen on chlorophyll fluorescence of blade of sugar beet. J Nucl Agric Sci 28:1918-1923

Zhang YS, WX Li (1997). Effects of nitrogen and phosphorus dosage ratio on yield and sugar content of sugar beet roots. Xinj Agric Sci 4:166-167

Zheng CX, FC Zhang, ZL Zhang, YH Kang (2014). Effect of limited irrigation and phosphorus fertilizer to nutrition absorption and utilization of winter wheat. Agric Res Arid Areas 32:102-107

Zhou JC, XC Wang, W Hu, QH Gong, QH Wang, YH Deng (2015). Main nutrient limiting factors on sugar beet yield and quality in China. Chin Agric Sci Bull 31:76-82

Zhou JC, XC Wang, YH Deng, XK Lin, Y Wang (2011). Effects of phosphorus stress on the root morphology and root exudates in different sugar beet genotypes. Chin Agric Sci Bull 27:157-161 